\title{
FAMILY BUSINESS SUCCESSION PLANNING IN THE GAMBIA TEXTILE MARKET
}

\author{
DOI: 10.17261/Pressacademia.2021.1421 \\ PAP- V.13-2021(10)-p.48-51
}

\section{Aminata Drammeh ${ }^{1}$, Nurgul Keles Taysir ${ }^{2}$}

${ }^{1}$ Istanbul Commerce University, Graduate School of Social Science, Istanbul, Turkey. aminatadrammeh05@gmail.com, ORCID: 0000-0001-6468-0015

${ }^{2}$ Istanbul Commerce University, Graduate School of Social Science, Istanbul, Turkey. nktaysir@ticaret.edu.tr, ORCID: 0000-0002-0232-2404

\section{To cite this document}

Drammeh A., Keles Taysir, N., (2021). Family business succession planning in the Gambia textile market. PressAcademia Procedia (PAP), V.13, 48-51.

Permanent link to this document: $h$ ttp://doi.org/10.17261/Pressacademia.2021.1421

Copyright: Published by PressAcademia and limited licensed re-use rights only.

\begin{abstract}
Purpose- This study aims to analyze family businesses in The Gambia Textile sector and their succession plans. Specifically, this paper seeks to find answers to these questions: 'Why the number of family businesses passing to the next generation is limited?" and "What can be done to increase family business succession in The Gambia Textile Market?".

Methodology- The qualitative research method was used in this study to interact with people who own family businesses and understand how they transfer the company from founder to successors. Semi-structured interviews were conducted with ten (10) family business owners in the urban area, mainly in Serekunda (Kanifing Municipal Council) and Banjul (the capital city of The Gambia).

Findings- The findings revealed that only four passed to the second generation out of ten firms, and none of them had a written succession plan. The successors were identified based on experience, skills, abilities, responsibilities, customer relations, and interest in the family business. All successors were satisfied with their succession experience except one. Also, they noted that family members play an essential role in the family business. Additionally, six firms mentioned they do not have any succession plans for their family businesses.

Conclusion- Although most Gambia businesses are family businesses, they do not consider succession plans a necessary action. Due to the lack of family business succession planning, the number of family businesses passed to the next generation is limited.
\end{abstract}

Keywords: Family business, succession planning, textile industry

JEL Codes: M10, M19, L67

\section{INTRODUCTION}

The family business is the most critical contributor to wealth creation and employment, which plays a vital role in most countries' economic development (Ramadani \& Hoy, 2015). Senegović et al. (2015) mentioned that about 80 to $90 \%$ of worldwide private companies are family businesses. They employ more than $85 \%$ of the total employees and generate more than $75 \%$ of the economy's GDP. According to the authors, the average life span for family businesses is 24 years (Senegović et al., 2015). From the report of Family Enterprise USA (2013) Survey of Family Firms cited by Johnson (2021), it was found that above $60 \%$ of family business owners have the intention of "reducing the United States deficit and debt". However, the number of family businesses that pass to the next generation is limited. Johnson (2021) cited from Businessweek.com (2010) it was found that " $40 \%$ of U.S. family-owned businesses transition into a second-generation business, approximately $13 \%$ are passed down successfully to a third generation, while 3\% survive to a fourth or beyond".

\section{LITERATURE REVIEW}

De Falco (2016) indicated that there is still no specific definition of the family business. The author stated that a company might be considered a family business "when one or more families, related by blood ties, affinity, or solid alliances, control the enterprise" (De Falco, 2016, p.5). Chua et al. (1999) reviewed 250 articles and reached 21 different definitions. These definitions vary based on different combinations of ownership and management. Ramadani \& Hoy (2015) defined a family business as a firm where one or more family members are part of the board of directors; the company ownership and control are also in the family's hands. Machek \& Votavova (2015) stated that family business has three characteristics: a family member owns most of its shares, the controlling right, decision of share distribution, and final decisions are taken by the family members. Also, family members should hold the position in the top management and supervisory level of the company. Rubio et al. (2017) have differentiated family businesses and non-family businesses using five main concepts, which involve 
"management perception, family ownership, desire for continuity, family management, and family involvement in the business". According to Beehr (1997), there are advantages of family businesses in the market as the members will have a more substantial commitment, loyalty, and shared values towards their business's growth than that of non-family business. According to Devine (2017), family firms play a critical role in the world economy's stability as most of every country's Gross National Product (GNP) is from family businesses. It helps a lot in reducing the unemployment rate. Cioca et al. (2020) state that family firms always care for maintaining their culture and family legacy, motivating them to keep the business succession from generation to generation. Both Beehr (1997) and Macheck \& Votavova (2015) agreed that conflict is the main disadvantage in the family business as it can cause lots of impacts in the industry. According to Kasakin (2014), familism, which means prioritizing family, is the main reason why many family businesses fail. Mikušová et al. (2020) stated that most family firms experience poor economic outcomes due to not giving non-family members the opportunities given to family members. Most researchers indicated that family businesses should have a succession plan for their sustainability. Family succession can be defined as the transfer of family business ownership from one generation to another. Also, there must be a family business succession process which was defined by Devine (2017) as a process that includes "the process of planning for succession (that is 'succession planning'), the actual plan itself (that is 'the succession plan') and the succession event (that is the point at which succession from one generation to the next occurs)" (p.4). Akanwa (1997) stated that most succession plans fail due to the lack of managerial experience. Pandey et al. (2014), analyzed the challenges faced through this stage are either technology issues during the process like lack of adequate tools, lack of plans for the business, not having the best employees, and lack of formal process. Holte (2019) analyses six elements that generally affect the effective succession in family businesses which include: unhealthy family relations, the unwillingness of the incumbent to step aside, aptitude and unwillingness of the successor, succession planning, mutual role adjustment, and lack of open and honest communication.

Bewayo (2009) indicates that two elements affect family businesses in sub-Saharan Africa, including economic/political and social/cultural factors. The author also analysed the U.S. western models in the Sub Sahara African region to see whether the model is being followed for family business successions in the long-run period. The U.S. system theory model, which Bewayo (2009) implies that some owners of the family business may involve in the business and are not family members; they just have a share in the family business or properties, which do not exist in Africa as most family businesses are owned, controlled and financed by the family. The Family-first model may likely be found in Africa as it implies managing the business according to the family interest, whereas nothing like governance structure or family councils help when there are conflicts between the family management or ownership (Bewayo, 2009). The concentric model which Bewayo (2009) mentioned that its likely be found in Africa as it implies that the family business members work towards the founder's interest and primarily focus on the social responsibilities. In The Gambia, family businesses serve to create employment and contribute to economic diversification and transformation. Although family business is critical in a country's economy, only a limited number of firms pass to the next generation. No study was conducted before this paper to talk about family businesses and how they control the country. This study aims to help future researchers to observe essential points to analyze in the future.

\section{DATA AND METHODOLOGY}

This study adopted a qualitative research method. A semi-structured interview method was used to interact with people who own family businesses to understand how they transfer the company from founder to successors. Ten (10) family business owners who specialize in the textile business have participated in the interviews. The interviewees are from the urban area, mainly in Serekunda (Kanifing Municipal Council) and Banjul (the capital city of The Gambia). Out of Ten (10) participants, eight (8) interviews were conducted through Zoom, and the remaining two (2) were conducted via WhatsApp voice note due to poor internet connection to communicate through the zoom platform. The interview process took approximately an hour for each participant. The conversations were recorded to translate the data into English as all the interviews were done in Wollof (Local language) and transcribed.

\section{FINDINGS}

Table 1 illustrates the profiles of participants. Out of the data collected, the participants' age group range between 30 years to 60 years, and only four did conventional education while the rest went to traditional schools. Five of the participants do not have any prior work experience apart from the textile business while the other five do. Apart from participant MEJ engaged in the family business for five years, all the other participants were involved in family firms ranging from 10 years to 39 years.

Table 1: Participants' Profiles

\begin{tabular}{|c|c|c|c|c|c|}
\hline Participants & Role & Age & Education & Prior Work Experience & Years Involve in Family Business \\
\hline A.J. & Successor & 39 & Junior level & None & 23 \\
\hline K.T. & Successor & 48 & Quranic school & Electrician/5years & 24 \\
\hline S.O.J. & Successor & 34 & Senior-level & None & 14 \\
\hline M.E.J. & Successor & 32 & Tertiary level & Bank/4years & 5 \\
\hline O.J. & Founder & 56 & Quranic school & None & $26+$ \\
\hline A.B.J. & Founder & 60 & Quranic school & Farmer & 39 \\
\hline S.D. & Founder & 58 & Arabic school & None & 32 \\
\hline A.J. & Founder & 60 & Quranic school & Cosmetic dealer/10years + & 37 \\
\hline A.K. & Founder & 30 & Senior-level & None & 10 \\
\hline M.J. & Founder & 50 & Quranic school & Farmer & 35 \\
\hline
\end{tabular}


Table 2 presents the details of the participants' businesses. All the family firms are in the textile industry. The family firms are between 4 years to 40 years old, and four of them are in the second generation while the other six are in the first generation. The number of employees and the family members working in the business is indicated in Table 2. Four of them mentioned that they involve non-family members in the decisions like purchasing of the firm's goods and the rest do not involve them in any decision regarding the business.

Table 2: Business Details

\begin{tabular}{|c|c|c|c|c|c|}
\hline $\begin{array}{c}\text { Participant } \\
\text { S }\end{array}$ & Found & $\begin{array}{c}\text { Business } \\
\text { generation }\end{array}$ & $\begin{array}{l}\text { Year pass to } 2 \text { nd } \\
\text { generation }\end{array}$ & $\begin{array}{l}\text { Number of } \\
\text { employees }\end{array}$ & $\begin{array}{c}\text { Number of family } \\
\text { members }\end{array}$ \\
\hline A.J. & 1996 & Second & 2015 & 8 & 3 \\
\hline K.T. & 1997 & Second & 2002 & 2 & 3 \\
\hline S.O.J. & 1981 & Second & 2013 & 6 & 6 \\
\hline M.E.J. & 1990 & Second & 2018 & 10 & 7 \\
\hline O.J. & 1998 & First & - & 6 & 4 \\
\hline A.B.J. & 1982 & First & - & 4 & 2 \\
\hline S.D. & 1999 & First & - & 3 & 4 \\
\hline A.J. & 1984 & First & - & 4 & 4 \\
\hline A.K. & 2017 & First & - & 7 & 6 \\
\hline M.J. & 2012 & First & - & 2 & 2 \\
\hline
\end{tabular}

The details of the succession process such as the year they passed to the second generation, whether the succession was planned, who made the decision, how was it made, how was the successor identified was also ask. Out of the ten companies, four are in their second generation, and the other six are in their first generation. The results showed that all the succession decisions were made in an informal way of discussion, and none was done formally. Out of the four firms that pass to the second generation, two were planned, and the other two were not planned and accelerated by an event. The successors were identified based on experience, skills, abilities, responsibilities, customer relations, and interest in the family business. It was also found that all successors were satisfied with their succession experience except MEJ, who mentioned that she still needs more because she did not spend much time in the business field yet still needs guidance from her father. Our findings also reveal that only one participant, A.J., mentioned that family association helps them in financial difficulties and promotes most women in their family to start a business for themselves. Other participants noted that their family association is a separate body from the business. The findings showed that family members play an essential role in the family business. They work together to control the firm's day-to-day activities and maintain the relationship with leading customers. Most of the young ones are involved at an early age to get used to the business activities and be able to control them.

The findings revealed that six of the ten firms do not have a succession plan for their family business. Out of the four with a succession plan, only two are planning to transfer responsibilities to the next generation in a year or less, while the other two are planning it in the next 10 years to 15 years. To analyze what triggers them for not having a succession plan, K.T. mentioned that "no plan yet because of the business's slowness and no season for the textile business in The Gambia. Maybe in the next 10 years, I think I will be able to finalize whether the family business textile will continue, or we will invest in another family business". Another participant with no succession plan S.O.J. mentioned maybe in the next 10 years, and he will make the plan. Still, currently, he did not achieve what he wants in the business, yet he wants to take the company to another level beyond today. A.B.J. said in his words, "I will make the plan if I know that I cannot control it anymore, but at the moment, I do not have any succession plan". A.J. mentioned that "what is triggering me is that my elder child is a daughter, and I cannot pass it to her now as the African culture believes that all daughters should be under the control of their husband after getting married that is why I am training my son to be the successor". According to A.K., he does not have any succession plan yet as the business started not long ago, but he would like to make that plan maybe in 25 years. Also M.J. said in his words, "the reason is my sons that would have to be the best

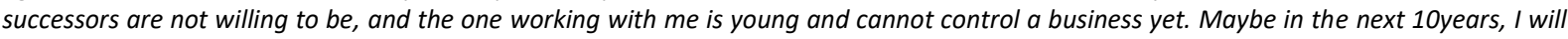
make that decision".

Our findings showed that family business holders face many challenges in handling their firms. The challenges mentioned were a high rental, high tax rate, a small population with high poverty rate, alarming currency rate, lack of price and market control, Covid-19 pandemic, lots of request from family members, familism, wholesale suppliers selling with low prices, high electricity bills, textile materials go out fashion within a short period, lack of trustworthy employees and online ordering. Findings also reveal that a life experience that will contribute to a successful business succession is to be educated, have experience, discipline, respect, being honest, trustworthy, patient, and good communication skills as they deal with customers directly. Also, participants analyzed that it is vital to have good management skills, willing to learn, have business strategies, vision, encouragement from both family members and the government.

We found out that there are some experiences that family business holders would like to use for future succession and the ones they would not use. Participant A.J. mentioned that he would not use any current experience for future succession because of lack of control and records. K.T. mentioned that he would like to have a succession plan so that the upcoming generation can know their responsibilities. S.O.J., said that they would like to continue with the current management style because everything is under control, and monthly salary for family members will be considered. O.J. mentioned that the experience of being honest will be encourage. According to A.B.J., the experience of taking records will always be considered, but the experience of going for something you do not have experience with will not be used in the future. S.D. mentioned that being honest and have a good relationship with the customer will forever be used in the future but employing based on familism and working with no proper control would not be used in future succession. A.J. also mentioned that having a good relationship with the customers is essential, but the experience of not giving responsibilities to the upcoming generation on time would not be used. 
According to A.K., having a business vision will be included in the future, and unnecessary spending will not be tolerated. Participant M.J. mentioned that the experience of being vigilant would be encouraged in future succession. Our findings also reveal the importance of a succession plan. The participants mentioned that a succession plan would help avoid misunderstanding or conflict within family members, help the business grow to many generations, help the next generation to be responsible in the family business as they will know their roles when their time to control arrive, encourage the young ones to love the business as they will be involved at the early age, it will help the old ones to retire on time, and with the education and resources of the current generation, they are the ones who can move the business forward better than the ones in their 60s.

\section{CONCLUSION}

From the findings revealed for this study, this paper can conclude that although most Gambia businesses are family businesses, they do not consider succession plans a critical action. From the interaction with family business owners in The Gambia, it was noticed that they have the experience, passion, and willingness to keep their businesses to many generations. Still, they always feel discouraged because of a lack of government help, especially in taxation and price control. The challenges they usually face make them lose hope, although they all believe that they can still do it and can make it in the future. As this is the first study conducted in The Gambia family business, we believe that our findings will support agencies. It will initiate the government to help the family business holders as they contribute a lot to its economy. We recommend doing more research on The Gambia family businesses. As it was found that most family businesses face difficulties in taking supplies from the country, this study also recommended microfinance institutions provide more loans with a favorable interest rate to encourage them in their business trips.

\section{REFERENCES}

beehr, T. A., Drexler, J. A., \& Faulkner, S. (1997). Working in small family businesses: empirical comparisons to non-family businesses. Journal Of Organizational Behavior, Vol. 18, 298-300.

Bewayo, E. D. (2009). Family Business In Africa: A Comparison with The U.S.-Western Model. The Journal of Global Business Issues, Volume 3 Issue 1, 172-180.

Chua, J. H., Chrisman, J. J., \& Sharma, P. (1999). Defining the Family Business by Behavior. 19-35.

Cioca, A., Wehbe, K., Popescu, D., \& Popescu, C. (2020). Innovation in Family Business. Proceedings of the 3rd International Conference on Economics and Social Sciences (2020), ISSN 2704-6524, pp. 786-802, 789-797.

Devine, A. (2017). An Exploration Of Governance Arrangements And The Succession Process Within Family Businesses. 4-28.

Falco, S. E. (2016). Defining and Classifying Family Businesses. In S. E. Falco, Family business, Ownership Governance and Management (pp. 3-5). Rome: settembre 2016.

Gil Bozer, Leon Levin, Joseph C. Santora,. (2017). Succession in family business: multi-source perspectives. Journal of Small Business and Enterprise Development, 10-12.

Holte, B. t. (2019). Making family business succession into family business success. The influence of soft issue-focused external advice on the bottlenecks in family business successions, 12-51.

Johnson, C. (2021). Retrieved April 13, 2021, from https://www.johnson.cornell.edu/smith-family-business-initiative-atcornell/resources/family-business-facts/

Kazakin, A. W. (2014). Determinants of Family Business Progress. Journal of Intercultural Management, 5-13.

Machek, O., \& Votavová, P. (2015). Advantages and Disadvantages of Family Entrepreneurship and How to Prevent Distress: Evidence from the Czech Republic. Mathematical Models and Computational Methods, 166 - 169.

Mikušová, M., Friedrich, V., \& Horváthová, P. (2020). Who is More Sustainable? Family Business or Non-Family Business? Czech Evidence. Sustainability 2020, 12, 5540, 5-6.

Pandey, D., \& Sharma, D. (2014). Succession Planning Practices and Challenges: Study of Indian Organisations. Symbiosis Institute of Management Studies Annual Research Conference (SIMSARC13) (p. 156). Procedia Economics and Finance.

Ramadani , V., \& Hoy, F. (2015). Context and Uniqueness of Family Businesses. 10.

Rubio, M. C., Lombardo, G. F., \& Martos, M. C. (2017). Influence of the lack of a standard definition of "family business" on research into their international strategies. European Research on Management and Business Economics 23 (2017) 132-146, 142.

Senegović, I., Bublić, V., \& Ćorić, G. (2015). Family Business Succession Risks: The Croatian context. ResearchGate, 1.

UNCTAD. (2016). National Entrepreneurship Policy Draft. UNCTAD. 